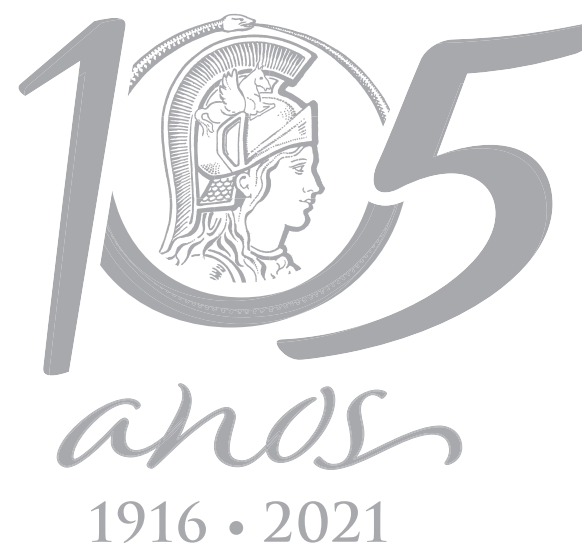

\title{
Bioprospection: in vitro antimicrobial potential of the leaf extract of mycorrhizal guava infected by Meloidogyne enterolobii on Klebsiella pneumoniae
}

\author{
MAÍRA C. MARCOLINO, JOÃO C.A. DE SOUSA JÚNIOR, CARLOS HENRIQUE A. DIAS, \\ CARINE R. NAUE, FLÁVIA B. DE SOUZA MELO \& MARYLUCE A. DA SILVA CAMPOS
}

\begin{abstract}
Guava (Psidium guajava L.), is adapted to tropical and subtropical climates, and, in addition to its nutritional value, has great medicinal potential. One of the medicinal effects is antibacterial, and this can be identified from the phytochemicals present in its various parts, especially the leaf, which contains flavonoids, phenols, and tannins, as well as phytocomposites with antibacterial action. Therefore, the interaction of this plant with arbuscular mycorrhizal fungi and Meloidogyne enterolobii is a biotechnological resource that can increase the production of secondary metabolites so that the guava ethanolic extract is effective against multidrug-resistant bacterial strains. Therefore, the objective of this study was to test the inhibitory action of mycorrhizal guava leaf extract and Meloidogyne enterolobii on strains of Klebsiella pneumoniae carbapenemase. Guava seedlings from cuttings were inoculated with Acaulospora longula, and later with Meloidogyne enterolobii; the leaves were harvested at two maturation times of the plant and placed in an oven. Next, a leaf extract was prepared using ethanol as a solvent. The extract was tested in multidrug-resistant strains of $K$. pneumoniae carbapenemase from operative wounds using disc diffusion methodology. The plant-AMF-phytonematode interaction positively potentialize the inhibitory action of guava leaf ethanolic extract on multidrug-resistant bacterial strains.
\end{abstract}

Key words: antibacterial, arbuscular mycorrhizal fungi, Glomeromycota, root-knot nematode.

\section{INTRODUCTION}

The human-nature interaction, specifically with the flora, has contributed to human evolutionary success. Indeed, it is conjectured that foraging for food plants contributed to the survival of the first hominids. Beyond the nutritional benefits, the medicinal effects of the plants (Ferreira Júnior \& Albuquerque 2018) could treat certain conditions presented by the organisms that consumed them.

Guava (Psidium guajava L.), native to Central and Latin America, thrives in a tropical and subtropical climate and can adapt to different soil types, except for poorly drained and clayey soils (Barbosa \& Lima 2010). It belongs to the Myrtaceae family, which, in addition to its food potential, also has medicinal properties. Albuquerque et al. (2007) and Agra et al. (2008), in research on the traditional uses attributed to medicinal plants in Northeast Brazil, showed that guava is used to treat stomach pain, dysentery, digestive problems, headache, inflammation in general, gingivitis, and throat disorders; the roots, leaves, and flowers are the parts of the plants used for medicinal purposes. 
Phytochemical research has proven the applicability and antimicrobial efficacy of guava extracts. Among the main chemical constituents of guava are tannins, phenolic compounds, and flavonoids, which have antimicrobial action (Barbalho et al. 2012).

In 2017, the World Health Organization (WHO) published a list of 12 families of multiresistant bacteria, warning that they represented a threat to human health and highlighted the need to formulate new compounds effective in combating these pathogens. The list is divided into priority pathogens: critical, high, and medium (OPAS 2017). On the critical priority list is Klebsiella pneumoniae, belonging to the family Enterobacteriaceae, a gram-negative bacterium commonly found in the normal human microbiota. However, it is characterized as an opportunistic pathogen, presenting multidrug resistance to antibiotics used in the clinical routine, and being a bacterium with increasing relevance in infections that occur in hospitals (Martinez \& Trabulsi 2008).

Klebsiella pneumonia is often the cause of infections in wounds resulting from surgical procedures. Medeiros et al. (2003) classified operative wounds into four categories according to the degree of contamination as clean, cleancontaminated, contaminated, and infected. Contamination of wounds prolongs and makes treatment difficult, and may cause post-surgical complications.

Therefore, bioprospecting research for phytopharmaceutical production from guava leaves aims to promote the evolution of antibiotic systems. As a biotechnological resource, arbuscular mycorrhizal fungi (AMF) may be used, as they increase the amount of bioactive compounds. The AMF are soil microorganisms that form a symbiotic mutualistic association with most plant species, providing nutrients to the plants that, in turn, provide products of photosynthesis for the fungus. These fungi bestow numerous benefits on plants, such as increased growth and tolerance to pathogens. In addition, they can improve the production of primary and secondary plant metabolites, such as phenolic compounds and total tannins (Pedone-Bonfim et al. 2013), contributing to the production of quality plant material for the pharmaceutical industry.

Another apparent resource comes from the interaction of arbuscular mycorrhizal fungi with other soil microorganisms. In the case of guava (P. guajava L.), it involves the interaction between the AMF and the phytonematode Meloidogyne enterolobii (commonly known as root-knot nematode), a sedentary root endoparasite, considered a limiting agent for the production of guava, which causes reduced nutrient absorption, leaf fall, and plant death (Barbosa \& Lima 2010). In addition, the plants infected with these pathogens produce more secondary metabolic compounds for example flavonoids (Chin et al. 2018). There is still no efficient chemical control for Meloidogyne; disease control is carried out by integrated management practices (Barbosa \& Lima 2010). However, the abandonment of areas with soil infested with Meloidogyne enterolobii is observed.

The interaction of these two microorganisms is due to the competition for space and nutrients between the AMF and Meloidogyne, a competition that can reduce the negative effects of the parasite on the plant (Campos et al. 2013, 2017) and increase the bioactive compounds of the guava leaves, thus increasing the medicinal potential of the plant, as seen in other plant species inoculated with AMF and infected by Meloidogyne (Sharma \& Sharma 2016, Gupta et al. 2015, Tiwari et al. 2017, Banuelos et al. 2014, Pandey et al. 2009). The competition also acts as a type of land-use management. In the areas affected by the root-knot nematode 
(Meloidogyne enterolobii), the guava trees can be used to produce medicinal compounds rather than fruit, thus, utilizing areas that would have been abandoned due to soil contamination by Meloidogyne enterolobii.

The existing literature highlights the need to discover compounds able to combat human pathogens of microbial origin, especially those most resistant to antibiotics used in clinical routine, and the possibility of doing this by eliciting plant responses through the introduction of symbiotic microorganisms and parasites. The objective of this study was to evaluate the potential of the leaf ethanolic extract of mycorrhizal guava seedlings infected with Meloidogyne enterolobii on Klebsiella pneumoniae carbapenemase strains obtained from surgical wounds.

\section{MATERIALS AND METHODS}

\section{Study location}

The guava seedlings were kept in an experimental screen, and the experiment was carried out at the Laboratory of Agricultural Cultures and Caatinga at the Submédio São Francisco - LACACSSF and at the Microbiology Laboratory, both located at the University of Pernambuco Campus Petrolina.

\section{Experimental design}

The design was completely randomized, consisting of eight treatments related to the presence or absence of AMF species Acaulospora longula, presence or absence of Meloidogyne enterolobii, in 15 or 45 days of inoculation of $M$. enterolobii. Thus, the ethanolic extracts of the guava leaves used in the experiment received the following treatments: guava seedlings inoculated with A. longula and with M. enterolobii with 15 days of inoculation of $M$. enterolobii (ALCN15), guava seedlings inoculated with $A$. longula and with $M$. enterolobii with 45 days of $M$. enterolobii inoculation (ALCN45), guava seedlings without $A M F$ inoculation and with $M$. enterolobii with 15 days of $M$. enterolobii inoculation (CCN15), guava seedlings without AMF inoculation and with $M$. enterolobii with 45 days of $M$. enterolobii inoculation (CCN45), guava seedlings inoculated with A. longula and without M. enterolobii with 15 days (ALSN15), guava seedlings inoculated with $A$. longula and without $M$. enterolobii with 45 days (ALSN45), guava seedlings without inoculation of AMF and without $M$. enterolobii with 15 days (CSN15), guava seedlings without AMF inoculation and without $M$. enterolobii with 45 days (CSN45). The experiment was carried out in triplicates.

\section{Experiment with guava seedlings}

Planting occurred prior to the experiments using the following methodology. Guava seedlings (Psidium guajava L. 'Paluma'), originating from cuttings, were purchased from Brasil Mudas, Petrolina-PE. These were removed from the substrate in which they were growing (a mixture of sawdust, vermiculite, and substrate sold for guava). The roots were washed, then they were transferred to black polyethylene bags containing $1 \mathrm{~kg}$ of the soil (collected in the Caatinga area, sterilized in an autoclave for three consecutive days at $121^{\circ} \mathrm{C} / 1 \mathrm{~h}$, and then ovendried). The chemical characterization of the soil was: P: $4.92 \mathrm{mg} \mathrm{dm}^{-3}, \mathrm{~K}: 0.25 \mathrm{cmol}_{\mathrm{c}} \mathrm{dm}^{-3}$, Ca: 1.1 $\mathrm{cmol}_{\mathrm{c}} \mathrm{dm}^{-3}, \mathrm{Al}: 0.0 \mathrm{cmol}_{\mathrm{c}} \mathrm{dm}^{-3}, \mathrm{Na}: 0.05 \mathrm{cmol}_{\mathrm{c}} \mathrm{dm}^{-3}$, Mg: $1.24 \mathrm{cmol}_{c} \mathrm{dm}^{-3}, \mathrm{pH}$ : 5.60, organic matter: 8.9 $\mathrm{g} \mathrm{kg}^{-1}$, and electrical conductivity: $0.22 \mathrm{dS} \mathrm{m}^{-1}$. Afterward, soil-inoculum (200 glomerospores, hyphae, and colonized roots) from Acaulospora longula, Spain, and N. C. Schenck (UFPE 21) was applied to the root of each plant. The spores of A. longula were multiplied using millet (Panicum miliaceum L.) as a host in sterile soil collected from the Caatinga. 
After 30 days of setting up the experiment, an aqueous suspension containing 3000 eggs and juveniles of $M$. enterolobii was added, extracted using the method of Hussey \& Barker (1973) from infected guava roots (Campos et al. 2013). The experiment was kept in an experimental screen, under ambient conditions of light, temperature (minimum $18{ }^{\circ} \mathrm{C}$ and maximum $30{ }^{\circ} \mathrm{C}$ ), and relative humidity (minimum 34.14\% and maximum 84.23\%), during 45 and 75 days of inoculation with AMF (15 and 45 days of inoculation of the nematode, respectively).

At 45 and 75 days, the following plant growth parameters were evaluated: height, leaf number, stem diameter, shoot and root fresh weight, and shoot dry weight. The leaves were quantified: total phenols, total flavonoids and total tannins. Parameters related to nematodes were also evaluated: number of galls and egg masses, counted in the roots with the aid of a stereomicroscope.

Total phenols and total tannins were determined according to the methodology proposed by Monteiro et al. (2006). The evaluation of total phenols was performed in a volumetric flask $(100 \mathrm{~mL}) 250 \mu \mathrm{L}$ of the extract, $5 \mathrm{~mL}$ of the Folin-Ciocalteu Reagent (10\%), $10 \mathrm{~mL}$ of Sodium Carbonate (7.5\%) were added and the volume completed to $100 \mathrm{~mL}$ with distilled water. After 30 minutes at rest, absorbance readings (760 nm) were performed, using tannic acid as the standard. Total tannins was performed in a conical flask, $6 \mathrm{~mL}$ of the extract, $1 \mathrm{~g}$ of powdered casein were added, with subsequent constant stirring (160 rpm / $25^{\circ} \mathrm{C}$ ). Subsequently, the samples were filtered, with the volume completed to $25 \mathrm{~mL}$ in a volumetric flask and quantification performed as described for the quantification of phenols. The tannin concentration was obtained by the difference between the value found in this reading and that obtained in the quantification of total phenols.
The levels of total flavonoids were estimated using the Araújo et al. methodology (2008), with some modifications. In a volumetric flask, $1 \mathrm{~mL}$ of the ethanolic extract, $0.6 \mathrm{~mL}$ of glacial acetic acid, $10 \mathrm{~mL}$ of pyridine methanol solution (2: $8 \mathrm{~V}$ / v) and $2.5 \mathrm{~mL}$ of ethanolic aluminum chloride solution (5\%), with the final volume of $25 \mathrm{~mL}$ completed with distilled water. After 30 minutes at rest, absorbance was measured (420 nm), using a routine to prepare the standard curve.

\section{Preparation of ethanolic extract}

At 15 and 45 days after inoculation with $M$. enterolobii (45 and 75 days after AMF inoculation, respectively), the leaves were removed from the seedlings in each treatment and oven-dried at $45{ }^{\circ} \mathrm{C}$ to a constant weight. Then, $500 \mathrm{mg}$ of leaves were perforated and transferred to amber flasks (80 mL), to which $20 \mathrm{~mL}$ of ethanol (95\%) was added. After 12 days in the dark at $25{ }^{\circ} \mathrm{C}$, the extract was filtered through gauze and later through qualitative filter paper and stored in a refrigerator $\left(4^{\circ} \mathrm{C}\right)$ (Brito et al. 2008).

\section{Preparation of discs with ethanolic extract}

The extracts were sterilized by filtration through a Millipore ${ }^{\circledR}$ filter $(0.25 \mu \mathrm{m}$ mesh opening); sterile $6 \mathrm{~mm}$ diameter quantitative filter paper discs (blue stripe) were soaked with $10 \mu \mathrm{L}$ of ethanolic extracts from the treatments mentioned above; disks soaked with $10 \mu \mathrm{L}$ of $70 \%$ ethanol were used as a negative control. All discs were placed in a sterile Petri dish to avoid contamination and to wait for the discs to dry.

\section{Bacterial isolate}

The Klebsiella pneumoniae carbapenemase bacteria were provided by the Clinical Analysis Laboratory of the University Hospital (HU), Petrolina-PE, and came from surgical wounds of patients admitted to the hospital. The bacteria 
were transported to UPE Campus Petrolina, where the experiment took place.

\section{Inoculation of bacteria and evaluation of experiments}

The bacteria were sown superficially in Petri dishes in Mueller Hinton medium, aliquots of bacterial suspension; the inoculum concentration used was between 0.8 and 1.0 and was verified by spectrophotometer following the McFarland scale. The disks prepared with vegetable ethanol extracts were distributed on the culture plate, ensuring a space of $2 \mathrm{~cm}$ from the edge and $3 \mathrm{~cm}$ between disks and the plates were kept in an incubator for $24 \mathrm{~h}$ at 37 ${ }^{\circ} \mathrm{C}$. After that period, the plates were placed on to evaluate the diameter of the inhibition zone. This was carried out with a ruler, and the absence of an inhibition halo was interpreted as the absence of antimicrobial activity.

\section{Data analysis}

The data were subjected to ANOVA (one way), and the means were compared by the Duncan test (5\%), using the Statistica 6.0 program (Statsoft 2002).

\section{RESULTS}

There was no significant difference in the growth of guava seedlings given the treatments (Table I). However, there was a reduction in the number of galls and egg masses of M. enterolobii (Figure 1) in the treatment using $A$. longula.

Regarding bioactive compounds, the amount of tannins did not differ between treatments, while the amount of phenols and flavonoids did differ between treatments. A greater amount of phenols was observed in the treatment CCN15 and CCN45 (104.43 and 103.94, respectively) (Table II). However, these treatments only differed statistically from treatments ALSN15 and ALSN45.

The amount of flavonoids had an increase of around $10 \%$ in the control treatments with nematodes (CCN15) and control without nematodes (CSN15), both at 15 days, which differed statistically from the control treatments without nematodes at 45 days (CSN45), inoculated with $A$. longula, without nematodes at 45 days (ALSN45) and inoculated with A. longula, with nematode at 45 days (ALCN45) (Table II).

Table I. Growth parameters of guava seedlings inoculated (AL) or not (C) with A. longula and infected (CN) or not (SN) with M. enterolobii, at 15 or 45 days after inoculation with M. enterolobii, maintained on an experimental screen. Averages are not statistically significant (Duncan's post-hoc test, alpha of 0.05 , test was performed between all treatments).

\begin{tabular}{|c|c|c|c|c|c|}
\hline Treatments & Leaf number & $\begin{array}{c}\text { Stem diameter } \\
\mathbf{( c m})\end{array}$ & Height $\mathbf{( c m )}$ & $\begin{array}{c}\text { Shoot fresh } \\
\text { weight } \mathbf{( g )}\end{array}$ & Root fresh weight (g) \\
\hline CSN15 & $8 \pm 5.29$ & $5.70 \pm 0.69$ & $39.7 \pm 6.03$ & $10.57 \pm 2.26$ & $10.83 \pm 3.59$ \\
\hline CSN45 & $10 \pm 0.58$ & $4.19 \pm 2.14$ & $40.2 \pm 2.12$ & $11.04 \pm 1.97$ & $8.15 \pm 6.01$ \\
\hline CCN15 & $12 \pm 4.04$ & $5.50 \pm 0.97$ & $36.0 \pm 13.55$ & $8.40 \pm 4.77$ & $12.29 \pm 2.77$ \\
\hline CCN45 & $14 \pm 9.29$ & $4.42 \pm 0.49$ & $28.3 \pm 3.79$ & $7.85 \pm 4.37$ & $7.87 \pm 3.72$ \\
\hline ALSN15 & $10 \pm 2.83$ & $4.86 \pm 0.75$ & $34.3 \pm 10.56$ & $10.21 \pm 2.53$ & $11.17 \pm 4.22$ \\
\hline ALSN45 & $12 \pm 2.63$ & $5.19 \pm 0.99$ & $36.0 \pm 4.08$ & $11.09 \pm 2.69$ & $16.79 \pm 2.01$ \\
\hline ALCN15 & $12 \pm 0.82$ & $4.49 \pm 0.86$ & $27.8 \pm 4.03$ & $9.16 \pm 2.93$ & $12.65 \pm 3.50$ \\
\hline ALCN45 & $13 \pm 1.41$ & $4.28 \pm 0.40$ & $34.0 \pm 4.83$ & $10.67 \pm 1.55$ & $10.92 \pm 4.63$ \\
\hline
\end{tabular}


The disks soaked with the ethanolic extract of $P$. guajava with the CSN45, CCN45, ALSN15, and ALCN15 showed reduced inhibition halo formations. Therefore, it was possible to analyze the effects of the presence of phytonematodes, $A M F$, and the time of plant maturation in the potential for antibacterial action. Treatment with A. longula and $M$. enterolobii at 45 days (ALCN45) differed statistically from the other treatments, with a greater inhibition halo (Figure 2) compared to the other treatments. As a result, a antibacterial performance was observed when multidrug-resistant strains of K. pneumoniae carbapenemase were exposed to the ethanolic extract of P. guajava after the plant had interacted with the AMF and the phytonematode, after 45 days of inoculation of the nematode.

The CSN15, CCN15, and ALSN45 treatments did not show any inhibitory action against the $K$. pneumoniae carbapenemase strains, nor did the control discs soaked with $70 \%$ ethanol showed any inhibition halo in any of the treatment plates (Figure 2).

\section{DISCUSSION}

The effects of inoculation of AMF usually appear in guava seedlings infected by $M$. enterolobii around 98 days after innoculation (Campos et al. 2013). The present experiment is the firt to measure it at 75 days. Campos et al. (2013) used three species of AMF and $M$. enterolobii in guava seedlings, in a 98-day experiment, and found that treatment with $A$. longula was the most promising. Sá \& Campos (2020) observed that all three AMF species (G. albida, A. longula and Claroideoglomus etunicatum) used in a 120day experiment benefited the growth of guava seedlings. In other plant species the beneficial effects of inoculation with AMF may appear as early as 45 days, as observed in Saad et al. (2011).

Regarding the parameters of Meloidogyne, in the present work, a reduction of these parameters was observed when the AMF was present (around half compared to control). This result is similar to that obtained by Campos et al. (2013) and Sá \& Campos (2020), who highlighted the use of AMF in reducing the amount of these nematodes in guava seedlings. This effect can be attributed to several factors such as competition for physical space, nutrients, reduction in the

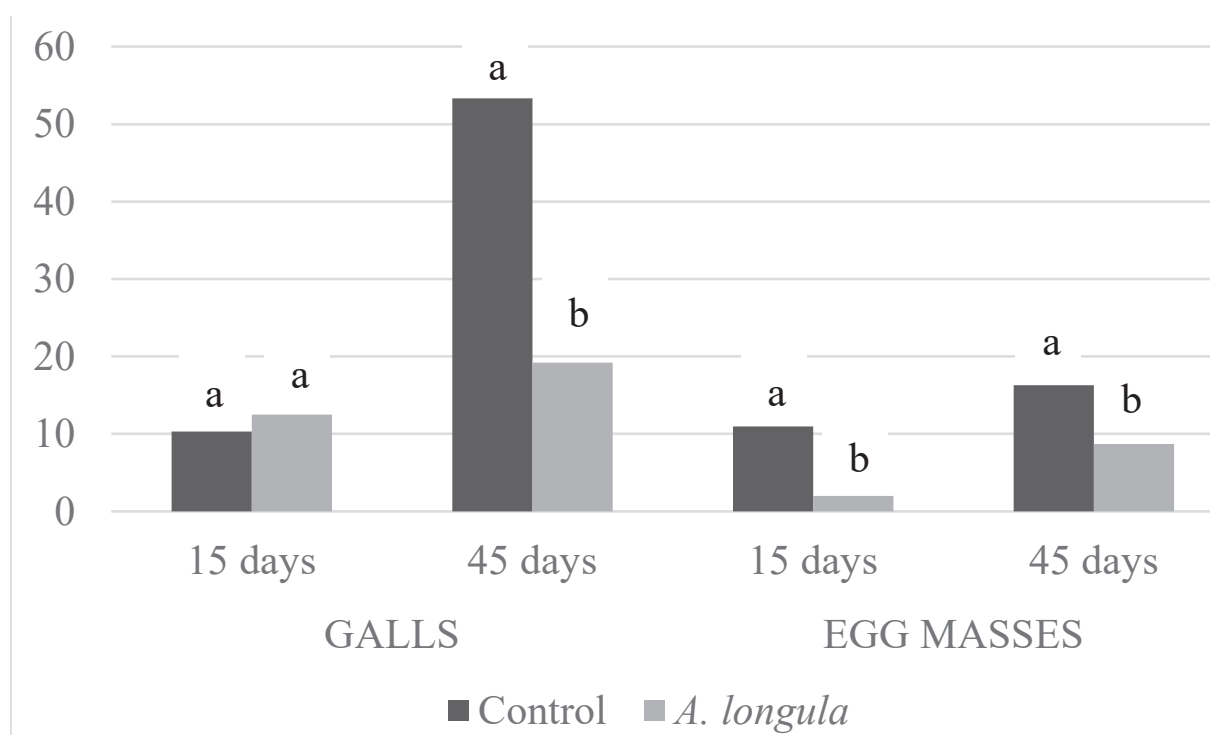

Figure 1. Number of galls on the roots and egg masses of $M$. enterolobii in guava seedlings inoculated with $A$. longula or without AMF (control), at 15 and 45 days after inoculation with $M$. enterolobii. Averages followed by the same letter (down the columns) are not statistically significant (Duncan's post-hoc test, alpha of 0.05). Post-hoc test was performed between the same day treatments. 
quantity and size of the giant cells that are a source of food for Meloidogyne, nematodes that take time to develop in adults, and even an increase in the production of plant defense compounds such as flavonoids and phenols (Campos 2020). Flavonoid biosynthesis has been associated with plant resistance against pathogens, including nematodes (Chin et al. 2018). However, it is possible that the flavonoids can be used by nematodes during the initial development of the feeding site to facilitate auxin accumulation and subsequently maintain maximum auxin for long-term maintenance and development (Chin et al. 2018). However, it seems more likely that the flavonoids' role in plantnematode interactions is defense, "through induce quiescence by slowing down their movement, resulting in periods of reversible inactivity, modify their migration towards the roots by repelling them, and kill them", rather than development control (Chin et al. 2018).

In general, in the presence of the nematode, the amount of phenols and flavonoids stood out in relation to treatments with AMF (around 5\%), with no additional effect of the presence of both organisms in increasing the production of these bioactive compounds. Accumulation of bioactive compounds, such as phenols, flavonoids, and tannins, in mycorrhizal plants or with pathogens is well documented in the literature (PedoneBonfim et al. 2018, Oliveira et al. 2013, Lima et al. 2015). However, experiments evaluating bioactive compounds when the two organisms are present at the same time are scarce, and the results varied.

Banuelos et al. (2014), in an experiment with the ornamental plant Impatiens balsamina infected by $M$. incognita and associated with AMF, obtained results similar to those of the present study. They observed that the treatment that produced the greatest amount of phenolic compounds was the one with the nematode alone. Morandi (1996) showed that the presence of AMF could cause the accumulation of phenolic and flavonoid compounds, the magnitude being smaller when compared to the interaction with pathogens that are more bioactive compounds in plants with pathogens than in plants with AMF.

However, other studies on joint treatments have been successful. Gupta et al. (2015), in an experiment with chamomile (Matricaria recutita L.) infected with $M$. incognita, observed that treatment with Bacillus megaterium, Trichoderma harzianum, and Glomus intraradices was the best, stimulating the production of phenols

Table II. Amount of bioactive compounds (tannins, phenols and flavonoids) in ethanol extract of guava leaves, inoculated (AL) or not (C) with A. longula, in the presence (CN) or absence (SN) of M. enterolobii, at 15 and 45 days after inoculation of the nematode.

\begin{tabular}{|c|c|c|c|}
\hline Treatments & Tannins $\mathbf{( m g / g )}$ & Phenols $(\mathbf{m g} / \mathbf{g})$ & Flavonoids $(\mathbf{m g} / \mathbf{g})$ \\
\hline CSN15 & $0.23 \pm 0.076 \mathrm{a}$ & $99.32 \pm 3.11 \mathrm{abc}$ & $12.60 \pm 0.67 \mathrm{a}$ \\
\hline CSN45 & $0.23 \pm 0.055 \mathrm{a}$ & $99.60 \pm 2.37 \mathrm{abc}$ & $9.47 \pm 1.14 \mathrm{bc}$ \\
\hline CCN15 & $0.28 \pm 0.077 \mathrm{a}$ & $104.43 \pm 1.59 \mathrm{a}$ & $12.97 \pm 1.21 \mathrm{a}$ \\
\hline CCN45 & $0.31 \pm 0.056 \mathrm{a}$ & $103.94 \pm 2.96 \mathrm{a}$ & $11.08 \pm 0.69 \mathrm{ab}$ \\
\hline ALSN15 & $0.22 \pm 0.083 \mathrm{a}$ & $92.61 \pm 10.18 \mathrm{bc}$ & $11.10 \pm 1.21 \mathrm{ab}$ \\
\hline ALSN45 & $0.17 \pm 0.042 \mathrm{a}$ & $90.99 \pm 0.81 \mathrm{c}$ & $7.90 \pm 1.16 \mathrm{c}$ \\
\hline ALCN15 & $0.27 \pm 0.038 \mathrm{a}$ & $103.09 \pm 3.28 \mathrm{ab}$ & $11.19 \pm 0.63 \mathrm{ab}$ \\
\hline ALCN45 & $0.27 \pm 0.036 \mathrm{a}$ & $101.93 \pm 4.32 \mathrm{abc}$ & $10.05 \pm 1.87 \mathrm{~b}$ \\
\hline
\end{tabular}

Averages followed by the same letter (down the columns) are not statistically significant (Duncan's post-hoc test, alpha of 0.05 ). 
and flavonoids. Higher phenolic content was observed in tomato (Lycopersicon esculentum CV. PT-3) associated with Rhizophagus irregularis AMF species and infected with $M$. incognita (Sharma \& Sharma 2017). In the same plant species infected with $M$. incognita, there was a greater quantity of phenols in the treatment with Meloidogyne, AMF, and Pseudomonas (Sharma \& Sharma 2016).

A review by Naseer et al. (2018) commented that guava has an antibacterial effect attributed to flavonoids and their derivatives, which may inhibit the growth of different bacteria species in various dilutions. Two flavonoids, quercetin and guajaverine, were discovered in guava trees and studied from an antimicrobial point of view, with the antimicrobial action being attributed to these compounds (Ngbolua et al. 2018, Arima \& Danno 2002). Growther \& Sukirtha (2018) observed that quercetin stood out quantitatively in guava leaf extract and had antibacterial and antifungal actions. Prabu et al. (2006) pointed out that guaijavarina has an action against Streptococcus. In a study on the concentration of quercetin in different parts of the guava tree, it was observed that the leaf had 60\% quercetin, with maximum leaf concentration occurring in the summer (Vargas-Alvarez et al. 2005). In the present study, the extract was made from seedling leaves, where the amount was small, given that the guava seedlings were only 75 days old and these bioactive compounds corresponded to only $1 \%$ of the dry weight of the plant (Agostini-Costa 2012). However, despite the small amount, the bioactive compounds seemed to act very efficiently.

Consistent with previous research, which proved the antibacterial effect of the ethanolic extract of P. guajava L. (Chanda \& Kaneria 2011, Saleh et al. 2015), in the present study, a halo of inhibition was observed in most treatments, indicating the antimicrobial effect of guava leaf extract. In tests with guava leaf ethanolic extracts on K. pneumoniae strains, Philip et al. (2015) and Ifeanyichukwu et al. (2015) reported the formation of 16 - and $15-\mathrm{mm}$ zones of inhibition, respectively. However, these studies do not provide information on the resistance level of the K. pneumoniae strains used in the research, which is a variable to be considered when intending to bioprospect the antibacterial action of a compound.

Biswas et al. (2013) and Morais-Braga et al. (2016) analyzed the effectiveness of P. guajava $L$. extract against Gram-positive and Gram-negative bacterial strains. They concluded that the guava

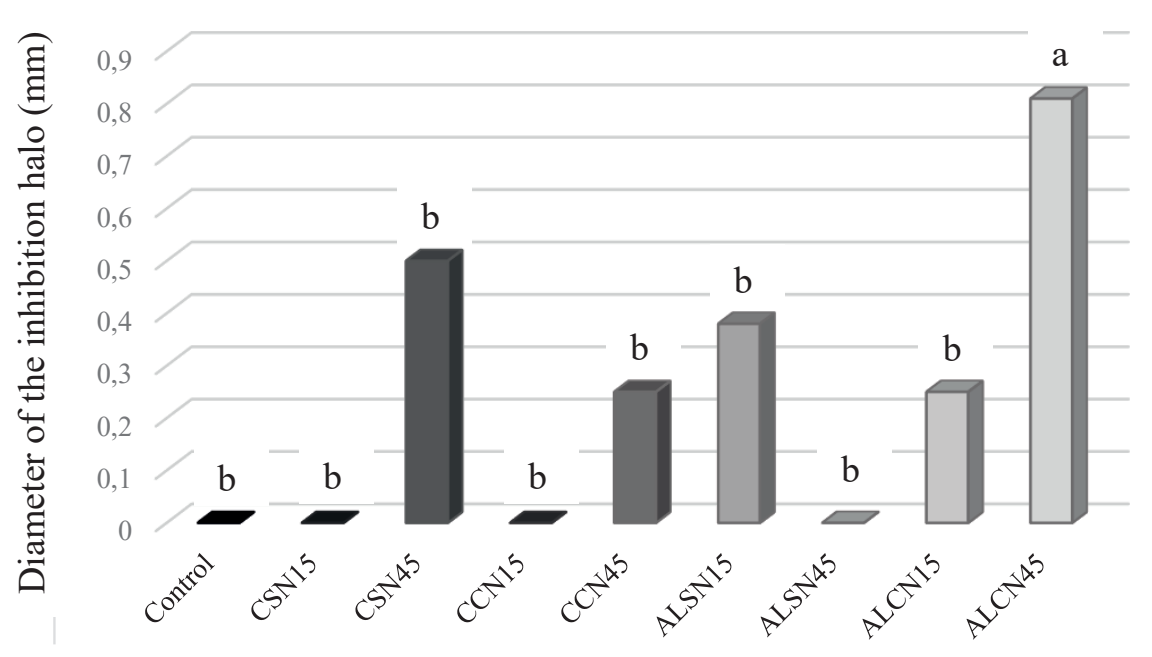

An Acad Bras Cienc (2021) 93(Suppl. 3) e20201559 8/12
Figure 2. Quantity in $\mathrm{mm}$ of inhibition halo formed around paper discs soaked in ethanol extracts of guava leaves from treatments with or without Acaulospora longula (AL) (C), with (CN) or without (SN) Meloidogyne, control (70\% alcohol), at 15 or 45 days of the experiment, on plates containing the Klebsiella pneumoniae carbapenemase bacterium ( $S D=0.4$ ). Averages followed by the same letter are not statistically significant (Duncan's post-hoc test, alpha of 0.05 ). 
leaf extract has no significant activity against Gram-negative bacterial strains. The potential of phytochemical compounds of guava should, therefore, be tested against multi-resistant bacterial strains. Moreover, the low effectiveness of P. guajava L. extracts against Gram-negative bacterial strains may be the reason for the low expression of inhibition halos observed in our work.

Biswas et al. (2013) also stated that a plant material's effect depends on its origin, variations in the extraction technique, time, concentration, quantity, and composition of secondary metabolites. With this information, evaluating the treatments, it is possible to observe the greatest expression of inhibition halos in the treatment with $A$. longula with $M$. enterolobii at 45 days (ALCN45), which combines the interaction of AMF and phytonematode with longer plant maturation time. It appears that the extract obtained a greater potential for antibacterial activity. This opens space for discussion and analysis of the effect of the AMF/ phytonematode interaction in increasing the production of secondary metabolic and plant protection, as discussed by Pedone-Bonfim et al. (2013) and Campos et al. (2013).

Although the amount of flavonoids did not stand out in that particular treatment (ranging from 7.90 to 12.97), it is likely that the majority of the flavonoids quantified in that treatment were quercetin or guajaverine (Ngbolua et al. 2018) and, for that reason, the treatment obtained better results.

The preparation of the ethanolic extract used in this study was carried out in a conventional way, that is, using the crude and non-concentrated extract, and the use of the crude extract can be effective because of its synergistic effect (Chanda \& Kaneria 2011). However, the concentrated extract can be as effective as the crude extract by concentrating the constituents through antimicrobial action. Therefore, the use of the concentrated ethanolic leaf extract of $P$. guajava L. with A. longula and $M$. enterolobii can present a greater inhibition halo against multi-resistant bacterial strains, which is an adjustment for use in later replications of the study.

\section{CONCLUSION}

This study corroborates the antimicrobial efficacy of guava leaf (P. guajava L.); however, the ethanolic leaf extract is not effective for multi-resistant bacterial strains. Nevertheless, when the plant is exposed to biotechnological interactions, which aim to increase the production of phytochemicals, it has a greater antibacterial potential. Thus, we can conclude that P. guajava, in interaction with AMF and the phytonematode, has the ability to combat multidrug-resistant bacterial strains and is still a management alternative for areas with soil affected by Meloidogyne. However, further studies are needed to test other methods of extracting the foliar extract of P. guajava L. and the use of concentrated extracts, in addition to testing other species of arbuscular mycorrhizal fungi and the interaction time of the organisms involved.

\section{Acknowledgments}

To the Dr. José Mauro da Cunha e Castro from the Brazilian Agricultural Research Corporation (Embrapa Semiárido) for the identification and supply of individuals from Meloidogyne enterolobii. The Institutional Program for excellence in the quality of the stricto sensu Support to the researcher APQ 2017 (University of Pernambuco) $n^{\circ}$ 229. The Coordenação de Aperfeiçoamento de Pessoal de Nivel Superior (CAPES) for supporting the Postgraduate Programa de Pós-Gaduação em Ciência e Tecnologia Ambiental. (PPGCTAS), Universidade de Pernambuco, Brazil. We would like to thank Editage (www.editage.com) for English language editing. 


\section{REFERENCES}

AGOSTINI-COSTA TS. 2012. Secondary Metabolites. In: Dhanarasu S (Ed). Chromatography and its applications. In Tech, p. 130-164.

AGRA MF, SILVA KN, BASÍLIO IJLD, FREITAS PF \& BARBOSA-FILHO $J M$. 2008. Survey of medicinal plants used in the region Northeast of Brazil. Braz J Pharmacogn 18: 472-508.

ALBUQUERQUE UP, MEDEIROS PM, ALMEIDA ALS, MONTEIRO JM, LINS NETO EMF, MELO JG \& SANTOS JP. 2007. Medicinal plants of the Caatinga (semi-arid) vegetation of NE Brazil: A quantative aprroach. J Ethnopharmacol 114: 325-354.

ARAÚJO TAS, ALENCAR NJ, AMORIM EC \& ALBUQUERQUE UP. 2008. A new approach to study medicinal plants with tannins and flavonoids contents from the local knowledge. J Ethnopharmacol 120: 72-80.

ARIMA H \& DANNO G. 2002. Isolation of Antimicrobial Compounds from Guava (Psidium guajava L.) and their Structural Elucidation. Biosci Biotech Bioch 66: 1727-1730.

BANUELOS J, ALARCON A, LARSEN J, CRUZ- SANCHEZ S \& TREJO D. 2014. Interactions between arbuscular mycorrhizal fungi and Meloidogyne incognita in the ornamental plant Impatiens balsamina. J Soil Sci Plant Nutr 14: 63-74.

BARBALHO SM, FARINAZZI-MACHADO FMV, GOULART RA, BRUNNATI ACS, OTTOBONI AMMB \& NICOLAU CCT. 2012. Psidium Guajava (Guava): A Plant of Multipurpose Medicinal Applications. Med Aromat Plants 01: 1-4.

BARBOSA FR \& LIMA MF. 2010. A cultura da goiaba, second ed., Brasília, Distrito Federal. Embrapa Informação Tecnológica, $90 \mathrm{p}$.

BISWAS B, ROGERS K, MCLAUGHLIN F, DANIELS D \& YADAV A. 2013. Antimicrobial activies of leaf extracts of guava (Psidium guajava L.) on two Gram-negative and Grampositive bacteria. Int J Microbiol 1-7.

BRITO HO, NORONHA EP, FRANÇA LM, BRITO LMO \& PRADO AS. 2008. Análise da composição fitoquímica do extrato etanólico das folhas de Annona squamosa (ATA). Rev Bras Farm 89: 180-184.

CAMPOSMAS.2020. Bioprotection byarbuscularmycorrhizal fungi in plants infected with Meloidogyne nematodes: A sustainable alternative. Crop Protection 135.

CAMPOS MAS, SILVA FSB, YANO-MELO AM, MELO NF \& MAIA LC. 2017. Application of Arbuscular Mycorrhizal Fungi during the Acclimatization of Alpinia purpurata to Induce Tolerance to Meloidogyne arenaria. Plant Pathol J 33: 329-336.
CAMPOS MAS, SILVA FSB, YANO-MELO AM, MELO NF, PEDROSA EMR \& MAIA LC. 2013. Responses of guava plants to inoculation with arbuscular mycorrhizal fungi in soil infested with Meloidogyne enterolobii. Plant Pathol J 29: 242-248.

CHANDA S \& KANERIA M. 2011. Indian nutraceutical plant leaves as a potential source of natural antimicrobial agents. Formatex 01: 1251-1259.

CHIN S, BEHM CA \& MATHESIUS U. 2018. Functions of Flavonoids in Plant-Nematode Interactions. Plants 7: 1- 17.

FERREIRA JÚNIOR WS \& ALBUQUERQUE UP. 2018. Origem e evolução dos sistemas médicos, In: Ferreira Júnior WS, Santoro FR and Albuquerque UL (Eds), Nossa história evolutiva - plantas medicinais e a origem e a evolução da medicina, Recife: NUPPEA, p. 1-33.

GROWTHER L \& SUKIRTHA K. 2018. Phytochemical analysis and antimicrobial properties of Psidium guajava leaves and bark extracts. Asian J Pharm Pharm 4: 318-323.

GUPTA R, SAIKIA SK \& PANDEY R. 2015. Bioconsortia Augments antioxidant and yield in Matricaria recutita $\mathrm{L}$. against Meloidogyne incognita (Kofoid and White) Chitwood infestation. Proc Natl Acad Sci India 87: 335-342.

HUSSEY RS \& BARKER KR. 1973. A comparison of methods of collecting inocula of Meloidogyne spp., including a new technique. Plant Dis Rep 57: 1025-1028.

IFEANYICHUKWU I, CHIKA E, EMMANUEL N, ANTHONIA O, NGOZI A \& AGABUS N. 2015. Preliminary Investigation of the Antibacterial Activity of Psidium guajava Extracts. Eur J Med Plants 7: 26-30.

LIMA CS, CAMPOS MAS \& SILVA FSB. 2015. Mycorrhizal Fungi (AMF) increase the content of biomolecules in leaves of Inga vera Willd. Seedlings. Symbiosis 65: 1-9.

MARTINEZ MB \& TRABULSI LR. 2008. Enterobacteriaceae, In: Trabulsi RL and Alterthun F (Eds), Microbiologia, São Paulo: Atheneu, p. 271-279.

MEDEIROS AC, NETO TA, FILHO AMD, JÚNIOR FELP, UCHÔA RAC \& CARVALHO MR. 2003. Infecção hospitalar em pacientes cirúrgicos de hospital universitário. Acta Cir Bras 18: 15-18.

MONTEIRO JM, ALBUQUERQUE UP, LINS NETO EM, ARAÚJO EL, ALBUQUERQUE MM \& AMORIM ELC. 2006. The effects os seasonal climate changes in the Caatinga on tannin levels in Myracrodruon urudeuva (Engl.) Fr. All, and Anadenanthera colubrina (Vell.) Brenan. Braz J Pharmacogn 16: 338-344. 
MORAIS-BRAGA MFB, SALES DL, SILVA FS, CHAVES TP, BITU VCN, AVILEZ WMT, RIBEIRO-FILHO J \& COUTINHO HDM. 2016. Psidium guajava L. and Psidium brownianum Mart ex DC. potentiate the effect of antibiotics against Grampositive and Gram-negative bacteria. Eur J Integr Med 8: 683-687.

MORANDI D. 1996. Occurrence of phytoalexins and phenolic compounds in endomycorrhizal interactions, and their potential role in biological control. Plant Soil 185: 241-251.

NASEER S, HUSSAIN S, NAEEM N, PERVAIZ M \& RAHMAN M. 2018. The phytochemistry and medicinal value of Psidium guajava (guava). Clin Phytoscience 4: 1-8.

NGBOLUA KN, LUFULUABO GL, MOKE LE, BONGO GN, LIYONGO $\mathrm{CI}$, ASHANDE CM, SAPO BS, ZOAWE BG \& MPIANA PT. 2018. A review on the Phytochemistry and Pharmacology of Psidium guajava L. (Myrtaceae) and Future direction. Discovery Phytomedicine 5: 7-13.

OLIVEIRA MS, CAMPOS MAS, ALBUQUERQUE UP \& SILVA FSB. 2013. Arbuscular mycorrhizal fungi (AMF) affects biomolecules content in Myracrodruon urundeuva seedlings. Ind Crop Prod 50: 244-247.

OPAS - PAN AMERICAN HEALTH ORGANIZATION. 2017. Resistência bacteriana. https://www.paho.org/bra.../ index.php?option=com_content\&view=article\&id=5592: novos-dados-revelam-niveis-elevados-de-resistenciaaos-antibioticos-em-todo-o-mundo\&Itemid=812. (accessed 30 October 2018).

PANDEY R, KALRA A \& GUPTA ML. 2009. Evaluation of bio- agents and pesticides on root- knot nematode development and oil yield of patchouli. Arch Phytopathol Plant Prot 42: 419-423.

PEDONE-BONFIM MVL, LINS MA, COELHO IR, SANTANA AS, SILVA FSB \& MAIA LC. 2013. Mycorrhizal technology and phosphorus in the production of primary and secondary metabolites in cebil (Anadenanthera colubrine (Vell.) Brenan) seedlings. J Sci Food Agr 93: 1479-1484.

PEDONE-BONFIM MVL, SILVA DKA, SILVA-BATISTA AR, OLIVEIRA AP, ALMEIDA JRGS, YANO-MELO AM \& MAIA LC. 2018. Mycorrhizal inoculation as an alternative for the sustainable production of Mimosa tenuiflora seedlings with improved growth and secondary compounds content. Fungal Biol 122: 918-927.

PHILIP CD, KUMARI RI \& LAVANYA B. 2015. Phytochemical analysis, antioxidant and antimicrobial activity of white e pink Psidium guajava Linnaeus. Int J Curr Pham Res 7: 8-10.
PRABU GR, GNANAMANI A \& SADULLA S. 2006. Guaijaverin - a plant flavonoid as potential antiplaque agent against Streptococcus mutans. J App Microbiol 101: 487-495.

SÁ CSB \& CAMPOS MAS. 2020. Arbuscular mycorrhizal fungi decrease Meloidogyne enterolobii infection of Guava seedlings. J Helminthol 94: e183.

SAAD AFSA, MASSOUD MA, IBRAHIM HS \& KHALIL MS. 2011. Management study for the root- knot nematodes, Meloidogyne incognita on tomatoes using fosthiazate and arbuscular mycorrhizal fungi. J Adv Agric Res 16(1): 137-147.

SALEH B, AL-HALAB L \& AL-MARIRI A. 2015. In vitro leaves and twigs antimicrobial properties of Psidium guajava $L$. (Myrtaceae). Herba Pol 61: 93-104.

SHARMA IP \& SHARMA AK. 2016. Physiological and biochemical changes in tomato cultivar PT- 3 with dual inoculation of mycorrhiza and PGPR against root- knot nematode. Symbiosis 71: 175-182.

SHARMA IP \& SHARMA AK. 2017. Co- inoculation of tomato with na arbuscular mycorrhizal fungus improves plant immunity and reduces root-knot nematode infection. Rhizosphere 4: 25-28.

STATSOFT. 2002. Statistica for Windows. Tulsa - USA.

TIWARI S, PANDEY S, CHAUHAN PS \& PANDEY R. 2017. Biocontrol agents in co- inoculation manages root knot nematode [Meloidogyne icognita (Kofoid and White) Chitwood] and enhances essential oil content in Ocimum brasilicum L. Ind Crops Prod 97: 292-301.

VARGAS-ALVAREZ D, SOTO-HERNÁNDEZ M, GONZÁLEZHERNÁNDEZ VA, ENGLEMAN EM \& MARTÍNEZ-GARZA A. 2005. Kinetics of accumulation and distribution of flavonoids in guava (Psidium guajava L.). Agrociencia 40: 109-115.

\section{How to cite}

MARCOLINO MC, DE SOUSA JÚNIOR JCA, DIAS CHA, NAUE CR, DE SOUZA MELO FB \& DA SILVA CAMPOS MA. 2021. Bioprospection: in vitro antimicrobial potential of the leaf extract of mycorrhizal guava infected by Meloidogyne enterolobii on Klebsiella pneumoniae. An Acad Bras Cienc 93: e20201559. DOI 10.1590/0001-3765202120201559.

Manuscript received on October 20, 2020;

accepted for publication on April 5, 2021

\section{MAÍRA C. MARCOLINO}

https://oricidorg/0000-0002-2041-2235

JOÃO C.A. DE SOUSA JÚNIOR'

https://orcid.org/0000-0003-4586-9060 


\title{
CARLOS HENRIQUE A. DIAS ${ }^{2}$
}

https://orcid.org/0000-0003-4215-3606

\section{CARINE R. NAUE ${ }^{2}$}

https://orcid.org/0000-0002-4008-7978

\section{FLÁVIA B. DE SOUZA MELO ${ }^{1}$}

https://orcid.org/0000-0002-1163-4282

\section{MARYLUCE A. DA SILVA CAMPOS ${ }^{1}$}

https://orcid.org/0000-0001-9552-5261

${ }^{1}$ Programa de Pós-Graduação em Ciência e Tecnologia Ambiental (PPGCTA), Universidade de Pernambuco (UPE), Campus Petrolina, Laboratório de Culturas Agrícolas e Caatinga no Submédio São Francisco, BR 203, Km 2, 56328-903 Petrolina, PE, Brazil

${ }^{2}$ Universidade Federal do Vale do São Francisco (UNIVASF), Campus Petrolina, Laboratório de Microbiologia, Av. José de Sá Maniçoba, s/n, 56304-205 Petrolina, PE, Brazil

Correspondence to: Maryluce Albuquerque da Silva Campos

E-mail:maryluce.campos@upe.br

\section{Author contributions}

\begin{abstract}
Maíra Cristina Marcolino and João Cleme Ananias de Sousa Júnior: Conceptualization, Validation, Investigation, Resources, Data Curation, Writing, Original Draft, Supervision; Carlos Henrique Araújo Dias: Conceptualization, Validation, Investigation, Writing - Review \& Editing; Carine Rosa Naue: Conceptualization, Resources, Writing - Review \& Editing; Flávia Bezerra de Souza Melo: Conceptualization, Validation, Investigation, Project administration, Writing - Review \& Editing; Maryluce Albuquerque da Silva Campos: Conceptualization, Methodology, Validation, Formal analysis, Resources, Writing Review \& Editing, Funding acquisition, Project administration.
\end{abstract}

\section{(cc) BY}

